\title{
Effect of phenol on biochemical status of an aquatic fern Salvinia natans
}

\author{
Ashis Sarkar, Swarnendu Roy* \\ Plant Biochemistry Laboratory, Department of Botany, University of North Bengal, Raja \\ Rammohunpur, Dist. Darjeeling, Pin - 734013, West Bengal, India \\ *Corresponding author, E-mail: swarnendubotany@nbu.ac.in
}

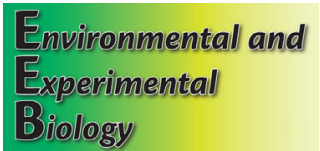

ISSN 2255-9582

UNIVERSITY OF LATVIA

\begin{abstract}
Phenols represent an organic group of toxic compounds, disposed of directly or indirectly into water bodies form agricultural and industrial sectors, causing critical impact on aquatic flora and fauna. Salvinia natans, an aquatic fern widely identified as a weed and known for its excellent ability to accumulate heavy metals and organic compounds, was selected for this study. In the present study, the ability of $S$. natans to withstand the toxic effects of phenol was assessed in terms of physiological and biochemical changes. Relative water content increased or remained stable up to $150 \mu \mathrm{M}$ phenol even after 10 days. Accumulation of osmolytes like soluble sugars and proline increased with phenol toxicity, thereby suggesting a resistance mechanism. Increase of activity of antioxidative enzymes up to $100 \mu \mathrm{M}$ phenol was also observed. Most importantly, there were no visible lesions indicating phenol toxicity on the plant tissues even after 10 days of treatment, which confirmed the phenol stress tolerance of this plant.
\end{abstract}

Key words: antioxidants, osmolytes, phenol, Salvinia natans, weed, water pollution.

Abbreviations: APX, ascorbate peroxidase; CAT, catalase; FW fresh weight; OD, optical density; POX, peroxidase; PVPP, polyvinylpolypyrrolidone; ROS, reactive oxygen species; RWC, relative water content; TW, turgid weight.

\section{Introduction}

Water is one of the fundamental components for the existence of life on earth. Any sort of changes in water quality directly influences all life forms. Agricultural and industrial wastes are recognized as major water pollutants, particularly in the form of pesticides, nutrients (phosphorus, sulphur and ammonium), heavy metals $(\mathrm{Pb}$, $\mathrm{Hg}, \mathrm{Cr}, \mathrm{Cu}, \mathrm{Cd}$, and $\mathrm{Zn}$ ), and various petrochemicals etc. (Hu, Cheng 2013). Low concentrations of these pollutants have effect on ecosystems, which can be treated to a certain extent, but an overload of these pollutants imparts critical and non-restorable damaging effect to ecosystems (Cooper 1993). Among the wide range of water pollutants, phenols play a notable role in polluting water bodies due to their significant presence in agricultural, domestic, industrial wastes, and several organic decaying sources (Anku et al. 2017). Petrochemicals and pharmaceutical industries, photography, textiles, sewage, paper, dye, metal, insecticides, pesticides and explosive production industries also discharge phenolic derivatives into river water (Bruce et al. 1987; Mahamuni, Pandit 2006).

Phenol, also known as carbolic acid (generic name: monohydroxy benzene), belongs to a class of organic compounds containing a hydroxyl group (one or more), generally forms colourless solid crystals at $25{ }^{\circ} \mathrm{C}$, and it is hygroscopic, with a sweet acrid odour, melting temperature of $43{ }^{\circ} \mathrm{C}$ and boiling temperature of $182{ }^{\circ} \mathrm{C}$ at normal pressure (Bruce et al. 1987). Some common derivatives of phenols, such as chlorophenols, catechol, methoxyphenols, monoterpenes etc., are present in byproducts of petrochemicals and pharmaceutical industries (Michałowicz, Duda 2005). The US Environment Protection Agency has listed phenolic compounds into the priority list of pollutants (Mahamuni, Pandit 2006).

A number of studies have reported the effect of phenolic compounds on aquatic flora and fauna and also strategies for the removal of such harmful and hazardous water polluting compounds. The toxicity of phenolic derivatives has been studied on some macroalgae and spermatophytes like Chara sp., Nitella sp., Elodea canadensis, Vallisneria spiralis, Lemna gibba, Lemna obscura, and Lemna minor (Stom, Roth 1981; Einhellig et al. 1985; Ramirez Toro et al. 1988; Christen, Theuer 1996). Macrophytes have been known to actively participate in the conversion of inorganic to organic carbon sources, maintenance of aquatic ecosystems, removal of phosphorous, nitrogen, suspended solids, heavy metals and other trace elements from waste water (Gupta 1980; Dhote 2007). These aquatic macrophytes also control the productivity of zooplankton (Stansfield et al. 1997), aquatic invertebrates by providing diversified habitats and ultimately increase fish production (Pennak 1971; Venugopal, Winfield 1993). Macrophytes are also used as a bio-indicators to detect pollutants, and 
in treatment processes to improve water quality (Eullaffroy, Vernet 2003; Rodrigues et al. 2016). Heavy metal biomonitoring has utilized macrophytes such as Juncus sp. (for $\mathrm{Zn}$ ) and Typha sp. (for $\mathrm{Ni}$ and $\mathrm{Cd}$ ), and acidification in river water is indicated by some liverworts (Tremp, Kohler 1995; Ladislas et al. 2012).

Salvinia natans is an aquatic macrophyte, considered as one of the worst weeds due to its prolific growth rate and worldwide distribution. This plant has been reported to exhibit excellent capability to accumulate and remove many inorganic and organic compounds from water bodies (Henry-Silva, Camargo 2008; Soares et al. 2008). Salvinia auriculata showed sensitivity under cadmium stress and tolerance to moderate salinity, thereby playing the role of an ecological indicator (Gomes et al. 2011; Rodrigues et al. 2016). Accumulation of chromium and aluminium in tissues of S. natans induced cellular damage and death, but S. natans showed some detoxification capability due to the presence of an antioxidative system and higher $\mathrm{H}^{+}$/ATPase activity during a stressed condition (Dhir et al. 2009; Mandal et al. 2013).

Extensive research has been done on phenols as water pollutants and its toxicity has been studied, but there is lack of information regarding the physio-biochemical changes in aquatic weeds to phenol exposure. Therefore, the present study was focused on the evaluation of physiochemical reactions of $S$. natans plants subjected to different concentration of phenol. This study therefore provides an insight into the response of $S$. natans to water pollutants like phenols.

\section{Materials and methods}

\section{Collection and culture of plant samples}

Salvinia natans (L.) All., a free-floating aquatic fern, was chosen as the plant material. The plants were collected from a pond adjacent to the University of North Bengal campus during the May and June, 2018 and maintained in the Departmental water reservoir with optimum nutrient conditions (rock phosphate, magnesium chloride and potassium nitrate in the ratio of 20:3:1 $\mathrm{g} \mathrm{L}^{-1}$ water) at 25 to $30^{\circ} \mathrm{C}$.

\section{Experimental setup and treatment}

Different concentrations of crystalline phenol were prepared in 0.1X Hoagland solution (Hoagland, Arnon 1950). Four different concentrations of phenol solutions $(50,100,150$ and $200 \mu \mathrm{M}$ ) were prepared along with water as a control. Approximately $5 \mathrm{~g}$ plant samples were then transferred into each of three replicates for each treatment and kept in ideal growth conditions throughout experiment.

\section{Relative water content}

Relative water content (RWC) was estimated according to the protocol of Barr and Weatherley (1962). Fresh leaf and root samples were taken from treatments, and weighted to obtain fresh weight (FW). Samples kept in fully moisture condition were weighed to obtain turgid weight (TW) and then dried at $80^{\circ} \mathrm{C}$ to determine the dry weight (DW). RWC was calculated by the following equation:

$$
\mathrm{RWC}=(\mathrm{FW}-\mathrm{DW}) /(\mathrm{TW}-\mathrm{DW}) \times 100(\%) .
$$

\section{Ascorbate concentration}

To extract ascorbate, $6 \%$ trichloroacetic acid was used and the filtrate was collected (Mukherjee, Choudhuri 1983). To estimate ascorbate, the spectrophotometric method with reagent $2 \%$ dinitrophenyl hydrazine was used. A standard curve of ascorbate was used to calculate concentrations.

\section{Proline concentration}

Proline extraction was done by $3 \%$ sulfosalicylic acid as described by Bates et al. (1973). The main reagent contained ninhydrin solution and the spectrophotometric absorbance was measured at $520 \mathrm{~nm}$. To quantify proline, a standard curve of L-proline was used.

\section{Total soluble sugar and reducing sugar concentration}

The standard protocol of Harborne (1998) was applied to extract total soluble sugar and reducing sugar with $95 \%$ ethanol. Total soluble sugar was estimated by anthrone reagent following the protocol given by Plummer (1978). Reducing sugar concentration was quantified by NelsonSomogyi method described by Marais et al. (1966) and the absorbance was measured in a spectrophotometer at 515 $\mathrm{nm}$ using a standard curve of D-glucose.

\section{Chlorophyll and carotenoid concentration}

Extraction of chlorophyll and carotenoids was performed with 100\% methanol. Estimation of chlorophyll and carotenoids was made by measuring the absorbance at $470 \mathrm{~nm}, 652.4 \mathrm{~nm}$ and $665.2 \mathrm{~nm}$ in a spectrophotometer. Calculation was done by the formula given by Lichtenthaler (1987):

$$
\begin{aligned}
\text { Chlorophyll } a= & 16.72 \times \mathrm{A}_{665.2}-9.16 \times \mathrm{A}_{653.4}\left(\mu \mathrm{g} \mathrm{mL}^{-1}\right) ; \\
\text { Chlorophyll } b= & 34.09 \times \mathrm{A}_{652.4}-15.28 \times \mathrm{A}_{665.2}\left(\mu \mathrm{gL}^{-1}\right) ; \\
\text { Carotenoids }= & \left(1000 \times \mathrm{A}_{470}-1.63 \times \mathrm{Chl} a-104.96 \times\right. \\
& \text { Chl } \left.b) / 221(\mu \mathrm{g} \mathrm{mL})^{-1}\right) .
\end{aligned}
$$

\section{Total phenol and ortho-dihydroxy phenol concentration}

For the extraction of phenols, $80 \%$ ethanol was used following the protocol of Mahadevan and Sridhar (1982). Total phenol was quantified by using $20 \% \mathrm{Na}_{2} \mathrm{CO}_{3}$ and Folin-Ciocalteau reagent (Bray, Thorpe 1954). Estimation of ortho-dihydroxy phenol was done by the method given by Arnows (1937).

\section{Estimation of proteins and antioxidative enzymes}

Quantification of soluble protein was done by Lowry's method (Lowry et al. 1951). Sodium phosphate buffer (50 $\mathrm{mM}, \mathrm{pH}$ 7.2) and polyvinylpolypyrrolidone (PVPP) under 
ice cold conditions were used to extract protein from plant tissues followed by centrifugation at $10000 \mathrm{rpm}$ at $4{ }^{\circ} \mathrm{C}$ for $15 \mathrm{~min}$. The supernatant obtained was used as the crude extract for measurement. Alkaline-copper tartarate solution and Folin-Ciocalteau reagent was reacted with the protein samples and the absorbance was taken in a UV-VIS spectrophotometer at $660 \mathrm{~nm}$. Quantification was done using a standard curve of bovine serum albumin.

For extraction of antioxidative enzymes, plant samples were crushed in a mortar-pestle in ice cold condition using liquid nitrogen. Sodium phosphate buffer $(0.05 \mathrm{M}, \mathrm{pH}$ 7.2) was used for ascorbate peroxidase (APX), and 0.05 $\mathrm{M}$ sodium phosphate buffer ( $\mathrm{pH}$ 6.8) for catalase (CAT) and peroxidase (POX) along with PVPP. Additionally, for extraction of APX, buffer also consisted of freshly prepared $1 \mathrm{mM}$ ascorbate. Then the homogenates were centrifuged at $10000 \mathrm{rpm}$ for $15 \mathrm{~min}$ at $4{ }^{\circ} \mathrm{C}$. Supernatants were used as crude enzyme extracts and estimation of protein content was done in each case following Lowry's method as described earlier.

CAT (EC 1.11.1.6) activity was assayed according to the protocol of Machly and Chance (1954) on the basis of the decomposition of $\mathrm{H}_{2} \mathrm{O}_{2}$ at $240 \mathrm{~nm}$ by the enzyme causing a change in absorbance. The absorbance was noted immediately at specific intervals up to $3 \mathrm{~min}$ in a UV-VIS spectrophotometer. The CAT activity was expressed as $\triangle \mathrm{OD} \mathrm{\textrm {mg } ^ { - 1 }}$ protein $\mathrm{min}^{-1}$.

POX (EC 1.11.1.7) activity was determined on the basis of the oxidation of o-dianisidine in the presence of $\mathrm{H}_{2} \mathrm{O}_{2}$ at $460 \mathrm{~nm}$ (Chakraborty et al. 1993). The change in absorbance was recorded at specific intervals up to $3 \mathrm{~min}$ and expressed as $\triangle \mathrm{OD} \mathrm{mg}{ }^{-1}$ protein $\mathrm{min}^{-1}$.

APX (EC 1.11.1.11) activity was assayed following the method of Asada and Takahashi (1987) on the basis of the decrease in absorbance at $290 \mathrm{~nm}$ resulting from the oxidation of ascorbate. Change in absorbance of the reaction mixture consisting of freshly prepared $\mathrm{L}$-ascorbate and $\mathrm{H}_{2} \mathrm{O}_{2}$, was measured immediately at specific intervals up to $3 \mathrm{~min}$ in a UV-VIS spectrophotometer and expressed as $\triangle \mathrm{OD} \mathrm{mg}{ }^{-1}$ protein $\mathrm{min}^{-1}$.

All antioxidative enzyme activities were also calculated by the following equation:

Activity $=\Delta \mathrm{OD} \times$ Dilution factor $\times$ Final volume $/$ Amount of protein $\times$ Time.

\section{Statistical analysis}

All the analyses were done in a completely randomized design with three biological replicates. For comparison, groups were subjected to one-way analyses of variance (ANOVA) followed by post hoc analysis using the Duncan's test at $p \leq 0.05$.

\section{Results}

\section{Relative water content}

The relative water content initially showed a significant increase in 50 and $100 \mu \mathrm{M}$ phenol treated plants, but a significant decrease was observed for 150 and $200 \mu \mathrm{M}$ treated plants in comparison to the control after 5 days of treatment at $p<0.05$ (Table 1). An increase in RWC by $12 \%$ was observed at $100 \mu \mathrm{M}$ concentration after 5 days of treatment. Similarly, an increase of $4 \%$ in the case of $50 \mu \mathrm{M}$ concentration after 10 days of treatment in comparison to the control was observed. At a concentration of $200 \mu \mathrm{M}$, significant decrease in the order of 4 and $9 \%$ was observed after 5 and 10 days of treatment respectively.

\section{Ascorbate and proline concentration}

After 5 days of phenol treatment the ascorbate concentration significantly decreased for all treatments of plants when compared to the control (Table 2). Maximum decrease of $44 \%$ was observed in $150 \mu \mathrm{M}$ and minimum decrease of $27 \%$ was observed in both 50 and $100 \mu \mathrm{M}$ phenol treatment compared to the control. After 10 days of treatment ascorbate concentration significantly increased for all phenol treatments when compared to the control at $p$ $<0.05$ (Table 2). Highest ascorbate accumulation (by 72\%) was observed in $100 \mu \mathrm{M}$ of phenol concentration compared to the control. After 10 days of treatment, however, accumulation of ascorbate in the plants significantly decreased in comparison to that at 5 days.

Highest increase in proline concentration was observed at $200 \mu \mathrm{M}$ phenol concentration ( $21 \%$ increase), after 5 days (Table 2). After 10 days, accumulation of proline significantly increased by $78 \%$ and $59 \%$ respectively in 50 and $100 \mu \mathrm{M}$ treated plants, but a significant decrease was observed at higher phenol concentrations in comparison to the control. Also, proline concentration was found to significantly increase along with increasing phenol

Table 1. Effect of different concentrations of phenol on relative water content and protein concentration. Values represent mean \pm SD. Different letters in the column indicates significant differences in comparison between treatments determined by one-way ANOVA and post hoc analysis by Duncan's test at $p<0.05$

\begin{tabular}{|c|c|c|c|c|}
\hline \multirow[t]{2}{*}{ Phenol $(\mu \mathrm{M})$} & \multicolumn{2}{|c|}{ Relative water content (\%) } & \multicolumn{2}{|c|}{ Protein $\left(\mathrm{mg} \mathrm{g}^{-1} \mathrm{FW}\right)$} \\
\hline & Day 5 & Day 10 & Day 5 & Day 10 \\
\hline 0 & $85.87 \pm 2.55 \mathrm{~B}$ & $85.05 \pm 1.04 b$ & $0.676 \pm 0.01 \mathrm{C}$ & $0.500 \pm 0.030 \mathrm{~b}$ \\
\hline 50 & $90.00 \pm 1.30 \mathrm{C}$ & $88.17 \pm 1.13 b$ & $1.115 \pm 0.010 \mathrm{E}$ & $0.700 \pm 0.017 \mathrm{c}$ \\
\hline 100 & $96.09 \pm 0.94 \mathrm{D}$ & $86.17 \pm 0.83 b$ & $0.595 \pm 0.010 \mathrm{~B}$ & $0.805 \pm 0.010 \mathrm{~d}$ \\
\hline 150 & $85.33 \pm 1.78 \mathrm{AB}$ & $87.93 \pm 2.65 b$ & $0.420 \pm 0.014 \mathrm{~A}$ & $0.350 \pm 0.018 \mathrm{a}$ \\
\hline 200 & $82.46 \pm 0.99 \mathrm{~A}$ & $78.23 \pm 1.99 \mathrm{a}$ & $0.760 \pm 0.022 \mathrm{D}$ & $0.360 \pm 0.020 a$ \\
\hline
\end{tabular}


Table 2. Effect of different concentrations of phenol on ascorbate and proline concentration. Values represent mean \pm SD. Different letters in the column indicates significant differences in comparison between treatments determined by one-way ANOVA and post hoc analysis by Duncan's test at $p<0.05$

\begin{tabular}{lcccc} 
Phenol $(\mu \mathrm{M})$ & \multicolumn{2}{c}{ Ascorbate $\left(\mathbf{m g ~ g}^{-1} \mathbf{F W}\right)$} & \multicolumn{2}{c}{ Proline $\left(\mathbf{m g ~ g}^{-\mathbf{1}} \mathbf{F W}\right)$} \\
& Day $\mathbf{5}$ & Day $\mathbf{1 0}$ & Day 5 & Day $\mathbf{1 0}$ \\
0 & $1.50 \pm 0.07 \mathrm{C}$ & $0.55 \pm 0.02 \mathrm{a}$ & $0.224 \pm 0.010 \mathrm{~B}$ & $0.304 \pm 0.005 \mathrm{c}$ \\
50 & $1.10 \pm 0.04 \mathrm{~B}$ & $0.80 \pm 0.07 \mathrm{bc}$ & $0.192 \pm 0.008 \mathrm{~A}$ & $0.544 \pm 0.009 \mathrm{e}$ \\
100 & $1.10 \pm 0.02 \mathrm{~B}$ & $0.95 \pm 0.08 \mathrm{~d}$ & $0.224 \pm 0.011 \mathrm{~B}$ & $0.484 \pm 0.006 \mathrm{~d}$ \\
150 & $0.85 \pm 0.05 \mathrm{~A}$ & $0.90 \pm 0.04 \mathrm{~cd}$ & $0.192 \pm 0.009 \mathrm{~A}$ & $0.242 \pm 0.006 \mathrm{a}$ \\
200 & $1.35 \pm 0.07 \mathrm{C}$ & $0.70 \pm 0.04 \mathrm{~b}$ & $0.272 \pm 0.012 \mathrm{C}$ & $0.272 \pm 0.013 \mathrm{~b}$
\end{tabular}

concentration when the plants were treated for longer duration (10 days) at $150 \mu \mathrm{M}$.

\section{Total soluble sugar and reducing sugar concentration}

After 5 days of treatment, the total soluble sugar concentration increased by $18 \%$ in both 100 and $150 \mu \mathrm{M}$ phenol treated plants, which was significant at $p<0.05$ (Table 3). However, significant decrease in total soluble sugar concentration by $13 \%$ in both $50 \mu \mathrm{M}$ and $200 \mu \mathrm{M}$ treatment after 5 days was observed when compared to control plants. After 10 days of treatment, significant increase in soluble sugar concentration by $18 \%$ in $100 \mu \mathrm{M}$ and $16 \%$ in $150 \mu \mathrm{M}$ phenol treated plants was recorded.

Reducing sugar concentration decreased (no statistical significance) in all the phenol treated plants after 5 days of treatment (Table 3). Highest decrease in reducing sugar concentration by $17 \%$ in $50 \mu \mathrm{M}$ phenol treated plants was observed after 5 days of treatment. Reducing sugar concentration after 10 days significantly decreased at $p<$ 0.05 in all the treatments except at $50 \mu \mathrm{M}$ concentration.
Highest decrease in reducing sugar concentration was observed in the $200 \mu \mathrm{M}$ treatment (58\%) when compared to control plants.

\section{Chlorophyll and carotenoid concentration}

Amount of chlorophyll a significantly decreased in 50, 100 and $150 \mu \mathrm{M}$ and increased (by 12\%) in $200 \mu \mathrm{M}$ phenol treated plants after 5 days (Table 4). Chlorophyll $b$ concentration on the other hand significantly decreased at $p>0.05$ in all plants; maximum reduction of $35 \%$ was observed in $200 \mu \mathrm{M}$ phenol treated plants after 5 days. Carotenoid concentration significantly increased by $40 \%$ in $100 \mu \mathrm{M}$ and decreased at 50 and $150 \mu \mathrm{M}$ phenol concentrations compared to the control after 5 days of treatment.

After 10 days of treatment, chlorophyll $a$ concentration significantly increased by $3.5 \%$ in $50 \mu \mathrm{M}$ and $21 \%$ in $100 \mu \mathrm{M}$ treatments (Table 4). Similarly, chlorophyll $b$ concentration increased significantly by $2 \%$ in $50 \mu \mathrm{M}$ and $23 \%$ in $100 \mu \mathrm{M}$ phenol treated plants after 10 days. After

Table 3. Effect of different concentrations of phenol on total soluble sugar and reducing sugar concentration. Values represent mean \pm SD. Different letters in the column indicates significant differences in comparison between treatments determined by one-way ANOVA and post hoc analysis by Duncan's test at $p<0.05$

\begin{tabular}{|c|c|c|c|c|}
\hline \multirow[t]{2}{*}{ Phenol $(\mu \mathrm{M})$} & \multicolumn{2}{|c|}{ Total soluble sugar $\left(\mathrm{mg} \mathrm{g}^{-1} \mathrm{FW}\right)$} & \multicolumn{2}{|c|}{ Reducing sugar ( $\left.\mathrm{mg} \mathrm{g}^{-1} \mathrm{FW}\right)$} \\
\hline & Day 5 & Day 10 & Day 5 & Day 10 \\
\hline 0 & $1.60 \pm 0.13 \mathrm{AB}$ & $1.60 \pm 0.11 b$ & $1.50 \pm 0.14 \mathrm{~A}$ & $1.05 \pm 0.14 b c$ \\
\hline 50 & $1.40 \pm 0.09 \mathrm{~A}$ & $1.40 \pm 0.12 \mathrm{a}$ & $1.25 \pm 0.19 \mathrm{~A}$ & $1.10 \pm 0.12 c$ \\
\hline 100 & $1.90 \pm 0.13 \mathrm{~B}$ & $1.90 \pm 0.14 c$ & $1.35 \pm 0.26 \mathrm{~A}$ & $0.80 \pm 0.11 b$ \\
\hline 150 & $1.90 \pm 0.11 \mathrm{~B}$ & $1.85 \pm 0.14 c$ & $1.45 \pm 0.21 \mathrm{~A}$ & $0.85 \pm 0.14 \mathrm{bc}$ \\
\hline 200 & $1.40 \pm 0.12 \mathrm{~A}$ & $1.38 \pm 0.12 \mathrm{a}$ & $1.30 \pm 0.15 \mathrm{~A}$ & $0.45 \pm 0.15 \mathrm{a}$ \\
\hline
\end{tabular}

Table 4. Effect of different concentrations of phenol on chlorophyll $a$, chlorophyll $b$ and carotenoid concentration.Values represent mean \pm SD. Different letters in the column indicates significant differences in comparison between treatments determined by one-way ANOVA and post hoc analysis by Duncan's test at $p<0.05$

\begin{tabular}{lcccccc} 
Phenol $(\boldsymbol{\mu M})$ & \multicolumn{2}{c}{ Chlorophyll $\boldsymbol{a}\left(\mathbf{m g ~ g}^{-\mathbf{1}} \mathbf{F W}\right)$} & \multicolumn{2}{c}{ Chlorophyll $\boldsymbol{b}\left(\mathbf{m g ~ g}^{-1} \mathbf{F W}\right)$} & \multicolumn{2}{c}{ Carotenoids $\left(\mathbf{m g ~ g}^{-\mathbf{1}} \mathbf{F W}\right)$} \\
& Day 5 & Day 10 & Day 5 & Day 10 & Day 5 & Day 10 \\
0 & $0.342 \pm 0.014 \mathrm{D}$ & $0.512 \pm 0.016 \mathrm{~b}$ & $0.208 \pm 0.020 \mathrm{C}$ & $0.278 \pm 0.060 \mathrm{a}$ & $0.063 \pm 0.007 \mathrm{~A}$ & $0.087 \pm 0.046 \mathrm{a}$ \\
50 & $0.322 \pm 0.012 \mathrm{C}$ & $0.531 \pm 0.002 \mathrm{~b}$ & $0.183 \pm 0.013 \mathrm{AB}$ & $0.283 \pm 0.022 \mathrm{a}$ & $0.043 \pm 0.007 \mathrm{~A}$ & $0.109 \pm 0.007 \mathrm{a}$ \\
100 & $0.292 \pm 0.007 \mathrm{~B}$ & $0.648 \pm 0.025 \mathrm{c}$ & $0.170 \pm 0.040 \mathrm{AB}$ & $0.361 \pm 0.035 \mathrm{~b}$ & $0.105 \pm 0.023 \mathrm{~B}$ & $0.124 \pm 0.020 \mathrm{a}$ \\
150 & $0.268 \pm 0.012 \mathrm{~A}$ & $0.497 \pm 0.021 \mathrm{~b}$ & $0.140 \pm 0.025 \mathrm{~A}$ & $0.270 \pm 0.022 \mathrm{a}$ & $0.051 \pm 0.013 \mathrm{~A}$ & $0.091 \pm 0.021 \mathrm{a}$ \\
\hline 200 & $0.382 \pm 0.009 \mathrm{E}$ & $0.440 \pm 0.019 \mathrm{a}$ & $0.137 \pm 0.020 \mathrm{~A}$ & $0.242 \pm 0.043 \mathrm{a}$ & $0.068 \pm 0.001 \mathrm{~A}$ & $0.097 \pm 0.003 \mathrm{a}$
\end{tabular}


Table 5. Effect of different concentrations of phenol on total soluble sugar and reducing sugar concentration. Values represent mean \pm $\mathrm{SD}$. Different letters in the column indicates significant differences in comparison between treatments determined by one-way ANOVA and post hoc analysis by Duncan's test at $p<0.05$

\begin{tabular}{|c|c|c|c|c|}
\hline \multirow[t]{2}{*}{ Phenol $(\mu \mathrm{M})$} & \multicolumn{2}{|c|}{ Total phenol (mg g-1 FW) } & \multicolumn{2}{|c|}{ o-Dihydroxy phenol (mg g-1 FW) } \\
\hline & Day 5 & Day 10 & Day 5 & Day 10 \\
\hline 0 & $4.00 \pm 0.43 \mathrm{~A}$ & $9.00 \pm 0.17 \mathrm{a}$ & $0.95 \pm 0.02 \mathrm{~A}$ & $2.65 \pm 0.06 c$ \\
\hline 50 & $9.00 \pm 0.26 \mathrm{C}$ & $10.00 \pm 0.31 \mathrm{a}$ & $2.35 \pm 0.04 \mathrm{D}$ & $2.85 \pm 0.04 \mathrm{~d}$ \\
\hline 100 & $8.50 \pm 0.36 \mathrm{C}$ & $9.00 \pm 0.52 \mathrm{a}$ & $2.60 \pm 0.08 \mathrm{E}$ & $2.60 \pm 0.11 c$ \\
\hline 150 & $13.50 \pm 0.36 \mathrm{D}$ & $9.50 \pm 0.17 \mathrm{a}$ & $2.20 \pm 0.04 \mathrm{C}$ & $2.35 \pm 0.03 b$ \\
\hline 200 & $7.00 \pm 0.45 \mathrm{~B}$ & $9.50 \pm 0.26 \mathrm{a}$ & $2.00 \pm 0.11 \mathrm{~B}$ & $2.20 \pm 0.10 \mathrm{a}$ \\
\hline
\end{tabular}

10 days of treatment carotenoid concentration increased in all treatment and the highest increase (with no statistical significance), by $30 \%$, was in $100 \mu \mathrm{M}$ phenol treated plants.

\section{Total phenol content and o-dihydroxy phenol concentration}

Total phenolic concentration significantly increased for all four treatments, compared to control plants, after 5 days (Table 5). Highest accumulation of total phenolics was $337 \%$ in the $150 \mu \mathrm{M}$ phenol treatment. Similarly, after 10 days of treatment, total phenolic concentration increased in three treatments $(50,150$ and $200 \mu \mathrm{M})$. The highest increase of $11 \%$ was observed in $50 \mu \mathrm{M}$ phenol treated plants after 10 days of treatment.

After 5 days of treatment, o-dihydroxy phenolic concentration was also observed to be significantly higher in all the four treatment plants after 5 days (Table 5). Maximum accumulation of o-dihydroxy phenol, by $173 \%$, was observed in the $100 \mu \mathrm{M}$ phenol treatment. However, after 10 days of treatment, o-dihydroxy phenolic concentration was found to decrease in all the treatments, except in the $50 \mu \mathrm{M}$ treatment (significant increase of 7\%). Highest decrease in o-dihydroxy phenolic concentration by $17 \%$ was observed in $200 \mu \mathrm{M}$ treated plants after 10 days of treatment.

\section{Total soluble protein and antioxidative enzyme activity}

Protein concentration increased significantly by $64 \%$ in 50 $\mu \mathrm{M}$ and $12 \%$ in $200 \mu \mathrm{M}$ phenol treated plants in comparison to control plants after 5 days of treatment (Table 1). However, in the case of $100 \mu \mathrm{M}$ and $150 \mu \mathrm{M}$ phenol concentration, protein concentration significantly decreased at $p<0.05$, by $12 \%$ and $38 \%$, respectively. After 10 days of treatment, protein concentration significantly increased by $40 \%$ in 50 $\mu \mathrm{M}$ and $60 \%$ in $100 \mu \mathrm{M}$ concentrations in comparison to the control. Protein concentration in general decreased in all treatments after 10 days of treatment when compared to that of 5 day treated plants.

CAT activity was lower in all treatments except $150 \mu \mathrm{M}$ (31\% enhancement) concentration after 5 days of phenol treatment (Table 6). Maximum reduction of 58\% in CAT activity was observed in the $50 \mu \mathrm{M}$ phenol treatment after 5 days. However, after 10 days of treatment, significant change was observed only at $150 \mu \mathrm{M}$ (16\% increase). After phenol treatment, CAT activity significantly increased at 10 days compared to 5 day treated plants.

After 5 days of treatment, POX activity was found to be significantly higher by $41 \%, 173 \%$ and $13 \%$ in 100 , 150 and $200 \mu \mathrm{M}$ phenol treated plants respectively (Table 6). However, a significant reduction (by 62\%) in POX activity was found in $50 \mu \mathrm{M}$ phenol treatments after 5 days of treatment compared to the control. After 10 days of treatment, maximum increase up to $43 \%$ was observed with no statistical significance at $p<0.05$ in the case of 50 $\mu \mathrm{M}$ phenol treated plants compared to control plants (Table 6).

APX activity was found to be increased significantly at $p<0.05$ by $14 \%$ and $38 \%$ respectively in 100 and 150 $\mu \mathrm{M}$ phenol treated plants after 5 days (Table 6). Significant reduction (by 50\% and 20\%) of in APX activity was

Table 6. Effect of different concentrations of phenol on antioxidant enzyme activity. CAT, catalase; POX, peroxidase; APX, ascorbate peroxidase. Values represent mean \pm SD. Different letters in the column indicates significant differences in comparison between treatments determined by one-way ANOVA and post hoc analysis by Duncan's test at $p<0.05$

\begin{tabular}{|c|c|c|c|c|c|c|}
\hline \multirow{2}{*}{$\begin{array}{l}\text { Phe- } \\
\text { nol } \\
(\mu \mathrm{M})\end{array}$} & \multicolumn{2}{|c|}{ CAT ( $\triangle$ OD $\mathrm{min}^{-1} \mathrm{mg}^{-1}$ protein) } & \multicolumn{2}{|c|}{ POX ( $\triangle O O D$ min $^{-1} \mathrm{mg}^{-1}$ protein $)$} & \multicolumn{2}{|c|}{$\operatorname{APX}\left(\Delta \mathrm{OD} \mathrm{min}^{-1} \mathrm{mg}^{-1}\right.$ protein $)$} \\
\hline & Day 5 & Day 10 & Day 5 & Day 10 & Day 5 & Day 10 \\
\hline 0 & $0.00041 \pm 0.0001 \mathrm{~A}$ & $0.00055 \pm 0.0001 \mathrm{ab}$ & $0.0074 \pm 0.0027 \mathrm{AB}$ & $0.0035 \pm 0.0010 \mathrm{a}$ & $0.0026 \pm 0.0007 \mathrm{AB}$ & $0.0040 \pm 0.0016 b c$ \\
\hline 50 & $0.00017 \pm 0.0001 \mathrm{~A}$ & $0.00032 \pm 0.0001 \mathrm{a}$ & $0.0028 \pm 0.0008 \mathrm{~A}$ & $0.0050 \pm 0.0027 \mathrm{a}$ & $0.0013 \pm 0.0004 \mathrm{~A}$ & $0.0021 \pm 0.0008 \mathrm{~b}$ \\
\hline 100 & $0.00034 \pm 0.0001 \mathrm{~A}$ & $0.00025 \pm 0.0001 \mathrm{a}$ & $0.0118 \pm 0.0023 \mathrm{~B}$ & $0.0025 \pm 0.0010 \mathrm{a}$ & $0.0023 \pm 0.0008 \mathrm{AB}$ & $0.0019 \pm 0.0007 \mathrm{a}$ \\
\hline 150 & $0.00054 \pm 0.0005 \mathrm{~A}$ & $0.00064 \pm 0.0004 \mathrm{~b}$ & $0.0202 \pm 0.0062 \mathrm{C}$ & $0.0043 \pm 0.0016 \mathrm{a}$ & $0.0036 \pm 0.0023 \mathrm{C}$ & $0.0043 \pm 0.0016 c$ \\
\hline 200 & $0.00028 \pm 0.0001 \mathrm{~A}$ & $0.00042 \pm 0.0002 \mathrm{ab}$ & $0.0083 \pm 0.0027 \mathrm{AB}$ & $0.0035 \pm 0.0013 \mathrm{a}$ & $0.0021 \pm 0.0008 \mathrm{AB}$ & $0.0049 \pm 0.0013 c$ \\
\hline
\end{tabular}


also observed at 50 and $200 \mu \mathrm{M}$ phenol concentrations, respectively, after 5 days. After 10 days of treatment, APX activity was found to be significantly increased by $7 \%$ in 150 and $21 \%$ in $200 \mu \mathrm{M}$ treated plants (Table 6). Also, APX activity was found to be significantly higher after 10 days of treatment when compared to that of 5 day treated plants.

\section{Discussion}

Phenol phytotoxicity considerably affects plant growth. A previous study on duckweed (Lemna gibba) showed negative effects on the morphology and vegetative growth at 0.08 $\mathrm{mM}$ and $0.54 \mathrm{mM}$ concentrations of phenols (Barber et al. 1995; Sharma et al. 1997). However, in S. natans, no effects in terms of morphological changes were observed, which implies that morphology alone cannot establish the degree of tolerance, for which other physiological and biochemical parameters are required to be taken into consideration.

Ascorbate, an essential metabolite, plays a crucial role in cellular functions, and thus plants tend to accumulate it during stress in both photosynthetic and non-photosynthetic tissues. Ascorbate functions as both primary and secondary antioxidants, it eliminates ROS, plays a role in photoprotection, and preserves activity of enzymes (Noctor, Foyer 1998). At higher concentration of phenol $(150 \mu \mathrm{M})$, accumulation of ascorbate in $S$. natans significantly increased after 10 days of treatment, suggesting its protective response to phenol stress. This type of increase in ascorbate concentration has been observed in cases of heavy metal stress in bean seedlings (up to 14, 15, 17 and 19\% increase for $\mathrm{Pb}, \mathrm{Cu}, \mathrm{Cd}$ and $\mathrm{Hg}$ stress, respectively), pointing towards a similar mechanism of combating phenol stress in S. natans (Kirbag Zengin, Munzuroglu 2005).

It has been emphasized that proline act as an excellent osmolyte under a wide range of abiotic and environmental stresses, and in addition functions as a signaling molecule, metal chelator and as an antioxidative defense molecule (Abdul Jaleel et al. 2007; Misra, Gupta 2005; Yang et al. 2009). In the present study, proline accumulation at higher phenol concentrations was observed after 5 days of treatment, indicating the activation of a stress-responsive mechanism in S. natans. This is in agreement with results from another study where the exposure of soybean plants to bisphenol-A induced increased accumulation of proline in roots (Zhang et al. (2016).

Accumulation of soluble sugars and reducing sugars under stressed conditions also function as a solute, which helps in water influx and maintaining cellular turgidity, improving cellular osmolarity under stressed conditions (Hare et al. 1998). Total soluble sugar concentration was also found to increase at higher phenol concentration $(\geq$ $100 \mu \mathrm{M})$ after 5 days of exposure. However, with increasing phenol concentration, reducing sugar concentration decreased, indicating the reduced metabolism of the sugars in response to phenol stress.

Chlorophyll $a$ and $b$ concentration of $S$. natans plants decreased after 5 days of phenol exposure. Similar decrease in the concentration of chlorophyll $a$ and $b$ concentration was reported in S. natans on exposure to glyphosate and copper (Liu et al. 2019). However, in the current study, when the plants were exposed to phenol for longer duration, chlorophyll a and b concentration increased in plants treated by up to $100 \mu \mathrm{M}$ phenol, indicating a higher tolerance level. Also, several studies have reported the reduction of chlorophyll $a / b$ ratio due to environmental stresses. Decrease in chlorophyll $a / b$ ratio in mung bean plants subjected to heavy metal stress was reported (Tewari et al. 2002). However, in our study it was observed that the chlorophyll $a / b$ ratio increased after 5 days of treatment with increasing phenol concentrations, which remained unchanged after 10 days of treatment. Also, it has been acknowledged that carotenoid concentration tends to decrease in response to environmental stresses, for instance in case of Vicia faba and Zea mays plants subjected to salinity stress (Gadallah 1999; Singh et al. 2008). Under increasing phenol concentration, we also observed that the carotenoid concentration decreased after 5 days of phenol stress, but after 10 days of treatment carotenoid concentration increased up to $100 \mu \mathrm{M}$ concentration compared to the control, indicating relative tolerance to phenol stress. Also, accumulation of phenol and o-dihydroxy phenol significantly increased for all phenol treatments after 5 days and almost remained the same after 10 days of treatment.

Protein concentration generally increased due to moderate phenol treatment after 5 days and 10 days, but was found to decrease at higher phenol concentration. Previous studies on another aquatic plant, Spirodela polyrrhiza, exposed to arsenic and cadmium stress have shown a similar trend in protein concentration (Seth et al. 2007).

Under biotic and abiotic stress, plants produce an excessive amount of reactive oxygen species (ROS), which is involved in DNA damage and cytotoxicity. During stress condition a complex antioxidant system protects cellular organelles by scavenging ROS in plants (Noctor, Foyer 1998). The stress tolerance of any plant depends on the improved activities of its antioxidant enzymes, irrespective of the biosynthesis of proteins. In this study, we evaluated the activities of CAT, POX and APX in S. natans plants exposed to phenol stress. Among the antioxidative enzymes, CAT is considered as one of most important $\mathrm{H}_{2} \mathrm{O}_{2}$ scavenging enzymes (de Azevedo Neto et al. 2005). In this study, with increasing phenol concentrations, activity of CAT increased at $150 \mu \mathrm{M}$ concentration and was lower at highest concentration of phenol after 5 and 10 days of treatments. Similar findings were reported in Solanum lycopersicum subjected to nonylphenol exposure (Jiang et al. 2019). Enhanced CAT activity is associated with the reduction of ROS content in celsl, thereby providing cellular 
stability (Esfandiari et al. 2007). In our study, POX activity mainly increased at higher phenol treatments $(\geq 150$ $\mu \mathrm{M})$ after 5 days. Similar fluctuations in POX activity was reported in a study involving the effect of heavy metal stress in Kandelia candel and Bruguiera gymnorrhiza (Zhang et al. 2007). Similarly, APX activity was found to be increased at higher phenol concentration after 5 days of treatment. Also, comparatively higher APX activity was observed after 10 days of treatment. Similar observations have been reported in S. natans plants after exposure to glyphosate and copper (Liu et al. 2019). The increase of activity of antioxidative enzymes like CAT, POX and APX in S. natans could therefore be correlated with the better management of phenol stress contributing to the scavenging of ROS.

\section{Conclusion}

Salvinia natans is a free floating aquatic fern growing proliferously in water bodies. In the present study, the plant showed a high degree of stress tolerance to varying degree of stress imparted by phenol. The resistance of the plant could be initially suggested from the morphological status of the plant, which almost remain unaltered after 10 days of exposure to phenol stress. RWC content of the plant also showed low decline at high concentrations. Accumulation of phenol and soluble sugars at the initial stages of phenol exposure and the increase in the activities of antioxidative enzymes in plant tissues could be correlated to the unaltered morphological status of the plants subjected to phenol stress. Therefore, we can conclude that the plant is comparatively tolerant to phenol stress and further studies at the molecular level is essential for elucidating the mechanism of the stress tolerance in detail.

\section{Acknowledgements}

The authors are grateful to the University of North Bengal, West Bengal, India for providing the necessary infrastructure and funding for this work. The first author is also grateful to the University Grants Commission, India for financial assistance in the form of UGC-Junior Research Fellow. The authors have read the final version of the manuscript and declare that there are no conflicts of interests as such.

\section{References}

Abdul Jaleel C., Gopi R., Sankar B., Manivannan P., Kishorekumar A., Sridharan R., Panneerselvam R. 2007. Studies on germination, seedling vigour, lipid peroxidation and proline metabolism in Catharanthus roseus seedlings under salt stress. South African J. Bot. 73: 190-195.

Anku W.W., Mamo M.A., Govender P.P. 2017. Phenolic compounds in water: sources, reactivity, toxicity and treatment methods. In: Soto-Hernandez M., Palma-Tenango M., GarciaMateo M.R. (Eds.) Phenolic Compounds - Natural Sources, Importance, Applications. Intech Open, London. Pp. 420-443.

Arnow L.E. 1937. Colorimetric determination of the components of 3, 4-dihydroxyphenyl-alanine-tyrosine mixtures. J. Biol.
Chem. 118: 531-537.

Asada K., Takahashi M. 1987. Production and scavenging of active oxygen in photosynthesis. In: Kyle D.J., Bowler C.B., Arntzen C.B. (Eds.) Photoinhibition. Elsevier Science Publisher, Armsterdam. Pp. 227-288.

Barber J., Sharma H., Ensley H., Polito M., Thomas D. 1995. Detoxification of phenol by the aquatic angiosperm, Lemna gibba. Chemosphere 31: 3567-3574.

Barrs H.D., Weatherley P.E. 1962. A re-examination of the relative turgidity technique for estimating water deficits in leaves. Austr. J. Biol. Sci. 15: 413-428.

Bates L., Waldren R.P., Teare I.D. 1973. Rapid determination of free proline for water-stress studies. Plant Soil 39: 205-207.

Bray H.G., Thorpe W.V. 1954. Analysis of phenolic compounds of interest in metabolism. Methods Biochem. Anal. 1:27-52.

Bruce R.M., Santodonato J., Neal M.W. 1987. Summary review of the health effects associated with phenol. Toxicol. Industr. Health 3: 535-568.

Chakraborty U., Chakraborty B.N., Kapoor M. 1993. Changes in the levels of peroxidase and phenylalanine ammonia-lyase in Brassica napus cultivars showing variable resistance to Leptosphaeria maculans. Folia Microbiol. 38: 491--496.

Christen O., Theuer C. 1996. Sensitivity of Lemna bioassay interacts with stock-culture period. J. Chem. Ecol. 22: 11771186.

Cooper C.M. 1993. Biological effects of agriculturally derived surface water pollutants on aquatic systems-a review. J. Environ. Qual. 22: 402-408.

De Azevedo Neto A.D., Prisco J.T., Eneas-Filho J., Medeiros J.V., Gomes-Filho E. 2005. Hydrogen peroxide pre-treatment induces salt-stress acclimation in maize plants. J. Plant Physiol. 162: 1114-1122.

Dhir B., Sharmila P., Pardha Saradhi P., Nasim S.A. 2009. Physiological and antioxidant responses of Salvinia natans exposed to chromium-rich wastewater. Ecotoxicol. Environ. Safety 72: 1790-1797.

Dhote S. 2007. Role of macrophytes in improving water quality of an aquatic eco-system. J. Appl. Sci. Enivron. Manage. 11: 133-135.

Einhellig F.A., Leather G.R., Hobbs L.L. 1985. Use of Lemna minor L. as a bioassay in allelopathy. J. Chem. Ecol. 11: 65-72.

Esfandiari E., Fariborz S., Shekari F., Manouchehr E. 2007. The effect of salt stress on antioxidant enzymes activity and lipid peroxidation on the wheat seedling. Not. Bot. Hort. Agrobot. 35: $48-56$

Eullaffroy P., Vernet G. 2003. The f684/f735 chlorophyll fluorescence ratio: A potential tool for rapid detection and determination of herbicide phytotoxicity in algae. Water Res. 37: 1983-1990.

Gadallah M.A.A. 1999. Effects of proline and glycinebetaine on Vicia faba responses to salt stress. Biol. Plant. 42: 249-257.

Gomes M., Suzuki M., Cunha M., Tullii C. 2011. Effect of salt stress on nutrient concentration, photosynthetic pigments, proline and foliar morphology of Salvinia auriculata Aubl. Acta Limnol. Bras. 23: 164-176.

Gupta G.C. 1980. Use of water hyacinths in wastewater treatment (a brief literature review). J. Environ. Health. 43: 80-82.

Harborne A. 1998. Phytochemical Methods: A Guide to Mmodern Techniques of Plant Analysis. Springer Science \& bBusiness Media.

Hare P.D., Cress W.A., Van Staden J. 1998. Dissecting the roles of osmolyte accumulation during stress. Plant Cell Environ. 21: 
535-553.

Henry-Silva G., Camargo A.F. 2008. Valor nutritivo de macrófitas aquáticas flutuantes (Eichhornia crassipes, Pistia stratiotes e Salvinia molesta) utilizadas no tratamento de efluentes de aqüicultura. Acta Sci. Biol. Sci. 24: 519-526.

Hoagland D.R., Arnon D.I. 1950. The water-culture method for growing plants without soil. Circular California Agricultural Experiment Station 347: 1-32.

Hu Y., Cheng H. 2013. Water pollution during China's industrial transition. Environ. Dev. 8: 57--73.

Jiang L., Yang Y., Zhang Y., Liu Y., Pan B., Wang B., Lin Y. 2019. Accumulation and toxicological effects of nonylphenol in tomato (Solanum lycopersicum L.) plants. Sci. Rep. 9: 7022.

Kirbag Zengin F., Munzuroglu O. 2005. Effects of some heavy metals on content of chlorophyll, proline and some antioxidant chemicals in bean (Phaseolus vulgaris L.) seedlings. Acta Biol. Cracov. Bot. 8: 1-16.

Ladislas S., El-Mufleh A., Gérente C., Chazarenc F., Andrès Y., Béchet B. 2012. Potential of aquatic macrophytes as bioindicators of heavy metal pollution in urban stormwater runoff. Water Air Soil Pollut. 223: 877-888.

Lichtenthaler H.K. 1987. Chlorophylls and carotenoids: Pigments of photosynthetic biomembranes. In: Methods in Enzymology. Academic Press, pp. 350-382.

Liu N., Zhong G., Zhou J., Liu Y., Pang Y., Cai H., Wu Z. 2019. Separate and combined effects of glyphosate and copper on growth and antioxidative enzymes in Salvinia natans (L.) All. Sci. Total Environ. 655: 1448-1456.

Lowry O.H., Rosebrough N.J., Farr A.L., Randall R.J. 1951. Protein measurement with the folin phenol reagent. J. Biol. Chem. 193: 265-275.

Mahadevan A., Sridhar R. 1982. Methods in Physiological Plant Pathology. Sivakami Publication, Madras.

Maehly A.C., Chance B. 1954. The assay of catalases and peroxidases. Methods Biochem. Anal. 1: 357-424.

Mahamuni N.N., Pandit A.B. 2006. Effect of additives on ultrasonic degradation of phenol. Ultrason. Sonochem. 13: 165-174.

Mandal C., Ghosh N., Maiti S., Das K., Gupta S., Dey N., Adak M.K. 2013. Antioxidative responses of salvinia (Salvinia natans Linn.) to aluminium stress and it's modulation by polyamine. Physiol. Mol. Biol. Plants 19: 91-103.

Marais J., De Wit J.L., Quicke G.V. 1966. A critical examination of the Nelson-Somogyi method for the determination of reducing sugars. Anal. Biochem. 15: 373-381.

Michałowicz J., Duda R.O.W. 2005. Analysis of chlorophenols, chlorocatechols, chlorinated methoxyphenols and monoterpenes in communal sewage of Łódź and in the ner river in 1999-2000. Water Air Soil Pollut. 164: 205-222.

Misra N., Gupta A. 2005. Effect of salt stress on proline metabolism in two high yielding genotypes of green gram. Plant Sci. 169: 331-339.

Mukherjee S., Choudhuri M.J. 1983. Implications of water stressinduced changes in the levels of endogenous ascorbic acid and hydrogen peroxide in Vigna seedlings. Physiol. Plant. 58: 166-170.

Noctor G., Foyer C.H. 1998. Ascorbate and glutathione: Keeping active oxygen under control. Annu. Rev. Plant Physiol. Plant
Mol. Biol. 49: 249-279.

Pennak R.W. 1971. Toward a classification of lotic habitats. Hydrobiologia 38: 321-334.

Plummer D.T. 1978. The practice of column chromatography. In: An Introduction to Practical Biochemistry. McGraw-Hill, New York. 1978. Pp. 61-66.

Ramirez Toro G.I., Leather G.R., Einhellig F.A. 1988. Effects of three phenolic compounds on Lemna gibba g3. J. Chem. Ecol. 14: 845-853.

Rodrigues D.A., Filho V.S.C., Rodrigues A.A., Rampazzo D.F., Rodrigues C.L., Vasconcelos J.M., Magalhães P.A.N.R. 2016. Effect of cadmium on the morphology and anatomy of Salvinia auriculata. African J. Biotechnol. 15: 891-896.

Seth C.S., Chaturvedi P.K., Misra V. 2007. Toxic effect of arsenate and cadmium alone and in combination on giant duckweed (Spirodela polyrrhiza L.) in response to its accumulation. Environ. Toxicol. 22: 539-549.

Sharma H.A., Barber J.T., Ensley H.E., Polito M.A. 1997. A comparison of the toxicity and metabolism of phenol and chlorinated phenols by Lemna gibba, with special reference to 2,4,5-trichlorophenol. Environ. Toxicol. Chem. 16: 346-350.

Singh A.K., Singh R.A., Kumar S. 2008. Influence of salinity on seedling growth and metabolism in maize genotypes. Indian J. Plant Physiol. 13: 95-99.

Soares A., Guieysse B., Jefferson B., Cartmell E., Lester J.N. 2008. Nonylphenol in the environment: A critical review on occurrence, fate, toxicity and treatment in wastewaters. Environ. Int. 34: 1033-1049.

Stom D.I., Roth R. 1981. Some effects of polyphenols on aquatic plants: I. Toxicity of phenols in aquatic plants. Bull. Environ. Contamin. Toxicol. 27: 332-337.

Stansfield J.H., Perrow M.R., Tench L.D., Jowitt A.J.D., Taylor A.A.L. 1997. Submerged macrophytes as refuges for grazing Cladocera against fish predation: Observations on seasonal changes in relation to macrophyte cover and predation pressure. Hydrobiologia 342: 229-240.

Tewari R., Kumar P., Sharma P., Bisht S. 2002. Modulation of oxidative stress responsive enzymes by excess cobalt. Plant Sci. 162: 381-388.

Tremp H., Kohler A. 1995. The usefulness of macrophyte monitoring-systems, exemplified on eutrophication and acidification of running waters. Acta Bot. Gall. 142: 541-550.

Venugopal M.N., Winfield I.J. 1993. The distribution of juvenile fishes in a hypereutrophic pond: Can macrophytes potentially offer a refuge for zooplankton? J. Freshwater Ecol. 8: 389-396.

Yang S.L., Lan S.S., Gong M. 2009. Hydrogen peroxide-induced proline and metabolic pathway of its accumulation in maize seedlings. J. Plant Physiol. 166: 1694-1699.

Zhang F.-Q., Wang Y.-S., Lou Z.-P., Dong J.-D. 2007. Effect of heavy metal stress on antioxidative enzymes and lipid peroxidation in leaves and roots of two mangrove plant seedlings (Kandelia candel and Bruguiera gymnorrhiza). Chemosphere 67: 44-50.

Zhang J., Li X., Zhou L., Wang L., Zhou Q., Huang X. 2016. Analysis of effects of a new environmental pollutant, bisphenol a, on antioxidant systems in soybean roots at different growth stages. Sci. Rep. 6: 23782. 